Menara Perkebunan, 2002, 70(2), 35-49

\title{
Keragaman genetik klon-klon karet (Hevea brasiliensis Muell. Arg) yang resisten dan rentan terhadap Corynespora casiicola berdasarkan penanda RAPD dan AFLP
}

\author{
Genetic variation of rubber (Hevea brasiliensis Muell. Arg) clones resistance and \\ susceptible to Corynespora cassiicola using RAPD and AFLP markers

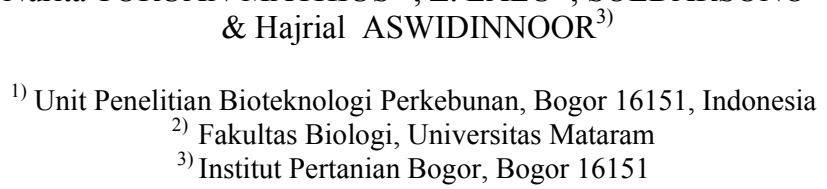

\section{Summary}

Corynespora leaf fall disease (CFLD) caused by the fungus Corynespora casiicola is one of the most important diseases of Hevea brasiliensis. CFLD was reported to cause serious damage on rubber productivity, and the disease has became more apparent in the recent years. The objectives of this study were (i) to analyze genetic similarities among several rubber clones resistance and susceptible to CFLD based on RAPD and AFLP markers, (ii) to compare the effectiveness of RAPD and AFLP markers. DNA genomic was extracted from young leaves of RRIM600, GT1, PB260, RRIC100, BPM1 (belongs to resistance group), PPN2058, PPN2444, and PPN2447 (belongs to susceptible group). Data were analyzed with NTSYS-pc program version 2.10, and a dendogram was created by cluster analysis using the unweighted pair group method on the basis of arithmetic averages (UPGMA). The results show that marker index AFLP (3.57) is higher than RAPD (1.02), it means that AFLP is more effective compared to $R A P D$. The average of genetic similarity AFLP (0.63) lower than RAPD (0.67) it means that AFLP is more discriminative than RAPD. Dendogram based on AFLP and $R A P D$ were the best with at 0.65 level of genetic similarity cluster divided into two cluster $A$ and $B$. Cluster A with a sub group Al consisted of RRIC100, PPN2058 and PPN244 are belongs to resistance group), and sub group A2 consisted of (RRIM600, GT1, BPM1 and PB 260 are belongs to susceptible group), while cluster B only PPN2447 is belong to susceptible group. AFLP analysis show that one AFLP band of $110 \mathrm{bp}$ resulting from PCR amplification using $\quad E-A C A / M-C A G$ $\left(E-A C A / M-C A G_{110}\right)$ primer pairs present in resistance clones, but absent in the susceptible clones. Meanwhile, application of 50 random primers decamer in RAPD analysis did not showed the specific band for either one of the group. It is concluded that AFLP marker analysis using EACA/M-CAG primer pair have a potential to differentiate resistance and the susceptible rubber clones to Corynespora. For the confirmation of the results more resistance and susceptible clones are needed for further test.

[Key words: Hevea brasiliensis, leaf-fall diseases, Corynespora casiicola, AFLP, RAPD, genetic similarity, UPGMA ]

\section{Ringkasan}

Penyakit gugur daun Corynespora (PDGC) yang disebabkan oleh patogen Corynespora asiicola, merupakan salah satu penyakit penting pada tanaman karet (Hevea brasiliensis). PGDC menyebabkan penurunan yang cukup serius terhadap produktivitas tanaman karet. Tujuan 
Toruan-Mathius et al.

penelitian ini adalah untuk (i) mengidentifikasi kesamaan genetik antar beberapa klon yang tergolong tahan dan rentan dengan marka RAPD dan AFLP, dan (ii) mempelajari efektivitas kedua marka tersebut. DNA genomik diekstraksi dari daun muda klon RRIM600, GT1, PB260, BPM1, RRIC100 (tergolong resisten), PPN2058, PPN2444, dan PPN2447 (tergolong rentan ). Data dianalisis dengan NTSYS-pc program versi 2.10. Dendogram dibuat dengan analisis pengelompokan menurut metode Unweighted Pair Group berbasis Arithmetic Avarages (UPGMA). Hasil yang diperoleh menunjukkan bahwa marka indeks AFLP $(3,57)$ lebih tinggi daripada RAPD $(1,02)$, sehingga AFLP lebih efektif dibandingkan dengan RAPD. Rata-rata perkiraan kesamaan genetik $\operatorname{AFLP}(0,63)$ sedikit lebih rendah dari $\operatorname{RAPD}(0,67)$ sehingga AFLP relatif lebih diskriminatif daripada RAPD. Dendogram berdasarkan integrasi AFLP dan RAPD adalah yang paling baik, dimana pada rata-rata perkiraan kesamaan genetik $(0,65)$ terbentuk dua kelompok yaitu A dan B. Kelompok A terdiri atas sub sub kelompok A1 yang beranggotakan (RRIC100, PPN2058 dan PPN244 yang tergolong resisten), dan sub group A2 yang beranggotakan (RRIM600, GT1, BPM1 dan PB 260 yang tergolong rentan) Sedang kelompok B beranggotakan hanya PN2447 yang tergolong rentan. Analisis AFLP menghasilkan satu pita AFLP dengan menggunakan pasangan primer EACA/M-CG (E-ACA/M-CAG 110 ) secara konsisten diperoleh dari klon karet yang resisten, namun tidak ditemukan pada klon yang rentan. Sementara itu, aplikasi 50 primer acak dekamer dalam analisis RAPD tidak menghasilkan pita spesifik untuk kedua kelompok yang diuji. Disimpulkan bahwa analisis AFLP menggunakan pasangan primer EACA/M-CAG berpotensi untuk membedakan klon karet yang resisten dan rentan terhadap Corynespora. Untuk mengkorfirmasi hasil yang diperoleh, perlu dilakukan pengujian terhadap klon-klon yang resisten dalam jumlah yang lebih banyak.

\section{Pendahuluan}

Tanaman karet Hevea secara ekonomi dan sosial merupakan komoditas perkebunan sangat penting bagi Indonesia, Malaysia, Thailand, India, Sri Lanka dan beberapa negara lainnya. Penyakit gugur daun Corynespora (PGDC) disebabkan oleh patogen Corynespora casiicola, merupakan salah satu penyakit penting pada tanaman karet di negara-negara penghasil karet di Asia. Awal penyebaran penyakit ini terjadi sekitar tahun 1980-an baik di Indonesia, Sri Lanka, Malaysia, India maupun Thailand. Penyakit ini semakin penting, ketika beberapa klon sebelumnya bersifat moderat dilaporkan menjadi rentan dan terserang hebat setelah beberapa tahun kemudian (Jayasinghe \& Silva, 1996; Shukor \& Hidir, 1996; Sinulinga et al., 1996; Rajalaksmy \& Kothandaraman, 1996).

Sampai sejauh ini belum ada fungisida yang direkomendasikan untuk mengendali-kan penyebaran penyakit ini di lapang. Satusatunya cara untuk mengatasi masalah tersebut adalah pekebun harus menggunakan bahan tanam dari klon yang tahan terhadap PGDC. Pemuliaan untuk mendapatkan tanaman yang tahan telah dilakukan, diawali dengan pemilihan klon yang tahan yang kemudian digunakan sebagai tetua dalam program persilangan. Informasi dan pemahaman mengenai ketahanan tanaman karet terhadap PGDC. Di samping itu keragaman genotip plasma nutfah karet merupakan modal dasar untuk keberhasilan program pemuliaan. Keragaman sangat penting untuk memperluas basis genetik dan kemungkinan mengeksploitasinya melalui penciptaan heterosis.

Beberapa teknik molekuler telah dikembangkan untuk menetapkan keragaman genetik antar klon karet dan plasma nutfah, diantaranya menggunakan isoenzim (Chevallier, 1988 ; Chaidamsari et al., 1993; dan Seguin et al., 1995 dan Yeang et al., 1998), RAPD Nurhaimi-Haris et al. (1998) dan Venkatachalam et al. (2002), dan RFLP Besse et al. (1994). Teknik RAPD tidak 
Keragaman genetik klon-klon karet yang resisten dan rentan.....

memerlukan pelacak DNA atau informasi mengenai sekuens DNA yang dilacak. Prosedurnya sederhana, dapat dilakukan secara maksimal untuk contoh dalam jumlah banyak, jumlah DNA yang diperlukan relatif sedikit, dan pengerjaannya tidak menggunakan senyawa radioaktif (Karp et al., 1996). Kelemahan teknik RAPD kadangkadang hasilnya tidak konsisten, disebabkan oleh rendahnya akurasi pengulangan hasil amplifikasi.

Prosedur AFLP lebih banyak membutuhkan tenaga dan lebih mahal daripada analisis RAPD, namun lebih banyak jumlah lokus yang dapat diperoleh dari setiap reaksi (Powell et al., 1996). Teknologi AFLP telah digunakan dalam studi keragaman intraspesies, di antaranya adalah kedelai (Glycine max) (Maughan et al., 1996), teh (Camelia sinensis L Kunt) (Paul et al., 1997), tanaman kakao (Perry et al., 1998) dan kapas (Pillay \& Myers, 1999). Yee et al. (1999) membandingkan penggunaan sistem marka RAPD dan AFLP untuk mengevaluasi kesamaan genetik antar tetua Vigna angularis (Azuki). Teknik AFLP juga telah banyak digunakan dalam studi keterpautan dengan sifat tertentu misalnya sifat ketahanan terhadap Cladosporium fulvum pada tomat (Thomas et al., 1995), sifat ketahanan terhadap Melampsora larici-populina pada Populus (Cervera et al., 1996), dan marka AFLP yang terpaut dengan gen avirulen alm 1 pada Leptosphaeria maculans (Pongam et al., 1998).

Tujuan penelitian ini adalah (i) membandingkan struktur keragaman genetik yang diperoleh dari analisis AFLP dan RAPD, (ii) mengevaluasi keragaman genetik klonklon Hevea yang tahan dan rentan terhadap Corynespora berdasarkan analisis RAPD dan AFLP.

\section{Bahan dan Metode}

\section{Bahan tanam}

Bahan tanam yang digunakan adalah klon yang tergolong resisten terhadap Corynespora yaitu RRIC 100, BPM1, PB 260, RRIM 600, dan GT1, serta klon yang tergolong rentan yaitu PPN2444, PPN 2447 dan PPN 2058.

\section{Isolasi DNA}

DNA genomik tanaman karet diisolasi dari 0,3 g daun muda dari masing-masing klon yang diuji menurut metode OrozcoCastillo et al. (1994). Endapan DNA dicuci sebanyak dua kali dengan $70 \%$ etanol, dikeringanginkan dan dilarutkan dalam 500 $\mu \mathrm{L}$ bufer TE (10mM Tris-HCL, 1mM EDTA, $\mathrm{pH}$ 7,5) dan diinkubasi pada suhu $37^{\circ} \mathrm{C}$ selama 1 jam dan ditambahkan $20 \mu \mathrm{L}$ RNAse A $(10 \mathrm{mg} / \mathrm{mL})$. DNA diendapkan dengan 2 volume $100 \%$ etanol dan 0,1 volume $3 \mathrm{M}$ Na-asetat. Konsentrasi DNA contoh ditetapkan dengan elektroforesis pada $1,4 \%$ agarosa (Gibco-BRL) menurut Sambrook et al. (1989).

\section{Analisis RAPD}

PCR dibuat dengan volumer $25 \mu \mathrm{L}$ yang mengandung $50 \mathrm{ng}$ DNA dari setiap klon, 10 pmoles primer DNA $(0,4 \mu \mathrm{M}), \quad 100 \mu \mathrm{M}$ setiap dNTP, 1 U Taq polimerase (Pomega) dan 2,5 $\mu \mathrm{L}$ Taq polimerase 10x bufer Promega (500 mM KCL, $15 \mathrm{mM} \mathrm{MgCl}_{2}, 100$ $\mathrm{mM}$ Tris-HCl $\mathrm{pH} 9,0)$. Primer dekamer dari Operon Technologies (Alameda, CA) atau abi dari Bresatec (Australia) digunakan dalam percobaan ini. Campuran reaksi PCR contoh 
Toruan-Mahius et al.

dalam tabung Eppendorf selanjutnya dilapisi dengan $25 \mu \mathrm{L}$ minyak mineral.

Reaksi amplifikasi DNA dilakukan menggunakan Thermolyne II Thermal Cycler, dengan kondisi PCR sebagai berikut : satu siklus 3 menit pada suhu $94^{\circ} \mathrm{C}$, dan diikuti dengan 45 siklus selama $1 \mathrm{~min}$. pada suhu $94^{\circ} \mathrm{C}$ (denaturasi), 1 menit pada suhu $37^{\circ} \mathrm{C}$ (anealing), 2 menit pada suhu $72^{\circ} \mathrm{C}$ (ekstensi). Seluruh produk amplifikasi DNA dilengkapi dengan ekstensi selama 1 menit pada suhu $72^{\circ} \mathrm{C}$. Setelah amplifikasi, produknya kemudian difraksinasi dengan elektroforesis $1,4 \%$ gel agarosa yang dijalankan pada $5 \mathrm{~V} / \mathrm{cm}$ dengan bufer TAE (40 mM Trisasetat, $1 \mathrm{mM}$ EDTA, pH 8.0) selama 3 jam, dan dideteksi menggunakan etidium bromida. Gel yang sudah diwarnai dengan etidium bromida divisualisasikan dengan pencahayaan UV transiluminator dan didokumentasi dengan alat foto Polaroid tipe 667.

Sebanyak 80 primer dekamer oligonukleotida baik dari Operon Technologies (Alameda, CA): Kit A - C atau abi dari Bresatec (Australia) diseleksi menggunakan beberapa klon karet. Primer yang menghasilkan hanya pita monomorfik, pola pita yang lemah tidak digunakan untuk analisis selanjutnya.

\section{Analisis AFLP}

Metode AFLP yang digunakan menurut metode standar dari Analysis AFLP ${ }^{\mathrm{TM}}$ System I (Cat.No.10544-013) GibcoBRL-Life Technologies. DNA genomik sebanyak $0,5 \mu \mathrm{g}$ dari masing-masing klon didigesti dengan sepasang enzim restriksi EcoRI/MseI pada suhu $37{ }^{\circ} \mathrm{C}$ selama 2,5 jam di dalam $1 \mathrm{x}$ bufer plus dan $5 \mu \mathrm{g} / \mathrm{mL}$ BSA. Untuk meligasi adapter, sebanyak $10 \mu \mathrm{L}$ campuran ligasi yang terdiri atas 5 pmoL EcoRI, 50 pmol dan MseI adapter, 1X T4 bufer ligase (Promega) dan satu Unit T4 ligase ditambahkan ke dalam campuran restriksi dan diinkubasi pada suhu ruang selama 2 jam. Produk ligasi diencerkan 1:5 volume/volume dengan bufer TE steril (10 mM EDTA, pH 7,5). Sekuen adapter EcoRI adalah 5' CTCGTA GACTGCG TACC dan CATCTGACGCATGGTTAA 5'. Adapter MseI 5'GACGATGAGTCCTGAG dan ACTCAGGACTCAT5'.

Ligasi yang sudah diencerkan selanjutnya digunakan dalam preamplifikasi PCR. Reaksi preamplification PCR mengandung $1 \mathrm{ng}$ DNA ligasi, $40 \mu \mathrm{L}$ reaksi PCR yang mengandung $5 \mu \mathrm{L}$ campuran ligasi 1:5 vol/vol, 50 ng EcoRI+1 primer, 50 ng MseI+ 1 primer, 1x PCR bufer plus, 0,2 $\mathrm{mM}$ masing-masing dNTP, dan 1 U Taq polimerase. Sekuen primer +1 adalah: 5' GACTGCGTACCAATTC-A(EcoRI) dan 5' GATGAGTCCTGAGTAA-C (MseI). Campuran reaksi ini kemudian diamplifikasi sebanyak 20 siklus dengan program $94^{\circ} \mathrm{C}$ selama 30 menit, $56^{\circ} \mathrm{C}$ selama 60 menit dan $72^{\circ} \mathrm{C}$ selama 60 menit. Setelah amplifikasi produknya diencerkan 1:50 volume/volume dalam bufer TE.

Seluruh contoh kemudian diamplifikasi selektif menggunakan 64 kombinasi primer. Primer untuk amplifikasi selektif (SA primer) sekuennya adalah EcoRI: 5'GACT GCGTA CCAATTC-AX (dimana $X$ salah satu dari yang berikut ini ACAGCCAC CCGCT GCGG). MseI: 5'GATGAGTCCT GAGTAACY (Y adalah salah satu dari yang berikut ini : AAAACAGATTACT GTT).

Sebanyak 33 pasangan primer selektif diseleksi menggunakan dua klon karet. Sebanyak 13 primer selektif dimasukkan dalam analisis akhir untuk menjaga seandainya ada profil amplifikasi DNA yang sangat lemah untuk penghitungan pita secara akurat, atau hanya pita monomorfik yang dihasilkan. Informasi mengenai 20 pasangan primer yang digunakan dalam analisis ini disajikan dalam Tabel 1. Reaksi PCR mengandung $5 \mu \mathrm{L}$ larutan pre amplifikasi yang sudah diencer- 
Keragaman genetik klon-klon karet yang resisten dan rentan.....

kan 1: 25 volume/volume, 5 ng EcoRI SA primer, 1x PCR bufer, 0,2 mM untuk masing-masing dNTP, 1 U Taq polimerase, dan $1,5 \mathrm{mM} \mathrm{MgCl}_{2}$.

Reaksi diamplifikasi pada: $94^{\circ} \mathrm{C}$ selama 30 detik, $65^{\circ} \mathrm{C}$ selama 60 detik dan $72^{\circ} \mathrm{C}$ selama 60 detik. Untuk dua siklus yang terdiri atas penurunan suhu anealing $2^{\circ} \mathrm{C}$ setiap dua siklus, sebanyak 8 siklus $\left(63^{\circ} \mathrm{C} \mathrm{x}\right.$ $2 ; 61^{\circ} \mathrm{C} \times 2 ; 59^{\circ} \mathrm{C} \times 2$ dan $57^{\circ} \mathrm{C} \times 2$ ). Duapuluh tiga siklus selanjutnya menggunakan suhu anealing $56^{\circ} \mathrm{C}$. Resultante produk PCR didenaturasi pada 7\% gel poliakrilamida yang sudah didenaturasi dengan 7 M Urea. Selanjutnya elektroforesis gel dijalankan selama 3,5 sampai 4,0 jam dalam 1X TBE, pada $65 \mathrm{~W}$ secara konstan menggunakan alat elektroforesis mini protean II (Promega) elektroforesis (lempengan kaca $10,0-8,5 \mathrm{~cm})$. Pemisahan produk AFLP divisualisasikan dengan pewarnaan perak nitrat dari Promega Silver Staining Kit untuk poliakrilamida.

\section{Analisis Data}

Ada atau tidaknya penanda di skor secara manual. Seluruh klon diskor untuk ada atau tidaknya penanda RAPD dan AFLP yang polimorfik, dan data dimasukkan ke dalam matriks biner sebagai peubah yang diskrit 1 untuk ada dan 0 untuk tidak adanya fragmen yang homologus. Data kemudian dianalisis dengan program NTSYS-pc (Numerical Taxonomy and Multivariate Analysis System, Version 2.10). Penghitungan polymorphic information content (PIC) dilakukan menurut Powell et al. (1996).

Matriks kesamaan dikonstruksi dari data biner dengan Jaccard's coefficients (JSC). Jarak JCC dari 0 ( untuk semua pita yang berbeda antara klon) dan 1 (untuk semua pita yang sama antar klon) Dendogram dibentuk dengan Unweighted Pair-Group Method, Arithmatice Average (UPGMA) algoritmik. Jumlah minimum primer yang diperlukan untuk mendiskriminasi semua klon yang diuji

Tabel 1. Sekuen dari dua puluh pasang primer AFLP dalam analisis keragaman genetik klon karet.

Table 1. Sequences of the tweenty pairs of selective AFLP primers used in analysis of the genetic variation of rubber clones.

\begin{tabular}{cc}
\hline \hline No & $\begin{array}{c}\text { Sekuen dari primer selektif (primer EcoRI-AX \& } \text { MseI }+ \text { CY }) \\
\text { Sequences of selective primers (EcoRI-AX \& Mse }+ \text { CY primers) }\end{array}$ \\
\hline 1. & GACTGCGTACCAATTC-ACA \& GATGAGTCCTGAGTAA-CAA \\
2. & GACTGCGTACCAATTC-AAC \& GATGAGTCCTGAGTAA-CAG \\
3. & GACTGCGTACCAATTC-ACA \& GATGAGTCCTGAGTAA-CAC \\
4. & GACTGCGTACCAATTC-ACA \& GATGAGTCCTGAGTAA-CTG \\
5. & GACTGCGTACCAATTC-ACA \& GATGAGTCCTGAGTAA-CTT \\
6. & GACTGCGTACCAATTC-ACT \& GATGAGTCCTGAGTAA-CAA \\
7. & GACTGCGTACCAATC-ACT \& GATGAGTCCTGAGTAA-CTA \\
8. & GACTGCGTACCAATTC-AGG \& GATGAGTCCTGAGTAA-CAG \\
9. & GACTGCGTACCAATTC-AGG \& GATGAGTCCTGAGTAA-CTA \\
10. & GACTGCGTACCAATTC-ACC \& GATGAGTCCTGAGTAA-CAA \\
11. & GACTGCGTACCAATTC-AGC \& GATGAGTCCTGAGTAA-CAA \\
12. & GACTGCGTACCAATTC-ACA \& GATGAGTCCTGAGTAA-CAG \\
13. & GACTGCGTACCAATTC-ACA \& GATGAGTCCTGAGTAA-CTA \\
14. & GACTGCGTACCAATTC-ACT \& GATGAGTCCTGAGTAA-CAG \\
15. & GACTGCGTACCAATC-ACC \& GATGAGTCCTGAGTAA-CTA \\
16. & GACTGCGTACCAATTC-AGC \& GATGAGTCCTGAGTAA-CTA \\
17. & GACTGCGTACCAATC-ACT \& GATGAGTCCTGAGTAA-CAT \\
18. & GACTGCGTACCAATTC-AGG \& GATGAGTCCTGAGTAA-CTT \\
19. & GACTGCGTACCAATTC-AAC \& GATGAGTCCTGAGTAA-CAA \\
20 & GACTGCGTACCAATTC-ACT \& GATGAG TCCTGAGTAA-CAC \\
\hline
\end{tabular}


Toruan-Mathius et al.

diperoleh melalui analisis statistik lanjut terhadap data RAPD atau AFLP dengan bootsrap menggunakan program WinBoot sebanyak 2.000 kali pengulangan sebagai uji tingkat goodness of fit kedua matriks yang diperoleh (Yap \& Nelson, 1996). Uji goodness of fit dari dendogram dan korelasi antara matriks kesamaan genetik RAPD dan AFLP diuji dengan uji Mantel (Mantel, 1967) dari NTSYS MXCOMP (Rohlf, 1993). Nilai rata-rata JSC dibandingkan dengan uji t. Nilai koefisien regresi (r) yang tinggi menunjukkan tingginya tingkat kesamaan, dan nilai yang rendah menunjukkan tingkat kesamaan yang rendah.

\section{Hasil dan Pembahasan}

\section{Analisis RAPD}

Dari 80 primer yang diseleksi, 30 primer diantaranya menghasilkan pita yang polimorfik. Ukuran produk amplifikasi berkisar antara 250 - 2250 pb (Gambar 1). Tidak ditemukan adanya pita RAPD yang spesifik untuk setiap klon, namun beberapa klon yang berasal dari tetua yang sama memiliki satu atau dua pita DNA yang unik. Tingkat polimorfisme antar klon yang diuji umumnya rendah (Gambar 2).

RAPD berdasarkan JSC memberikan konsistensi tingkat kesamaan berkisar antara $0,50-1,00$ dengan nilai tengah 0,75 . Tingkat goodness of fit RAPD berdasarkan dendogram UPGMA sangat berbeda nyata yaitu rRAPD $=0,87(\mathrm{p}<0,01)$ dengan nilai $\mathrm{r}$ integrasi $=0,90 \quad(\mathrm{p}<0,01)($ Tabel 2$)$. Pada tingkat fenogram 0,67 , diperoleh dua kelompok yaitu A dan B. A terdiri atas dua sub kelompok yaitu A1 yang beranggotakan klon RRIC 100, dan A2 terdiri atas dua sub kelompok, yaitu A1 beranggotakan RRIM 600, GT1, BPM1, PB260, dan sub kelompok A2 beranggotakan PPN2058, PPN2444 dan PPN 2447. Kelompok B hanya beranggotakan PPN 2447. Menurut Lapitan (1992) jumlah sekuen yang berulang berkorelasi dengan ukuran genom.

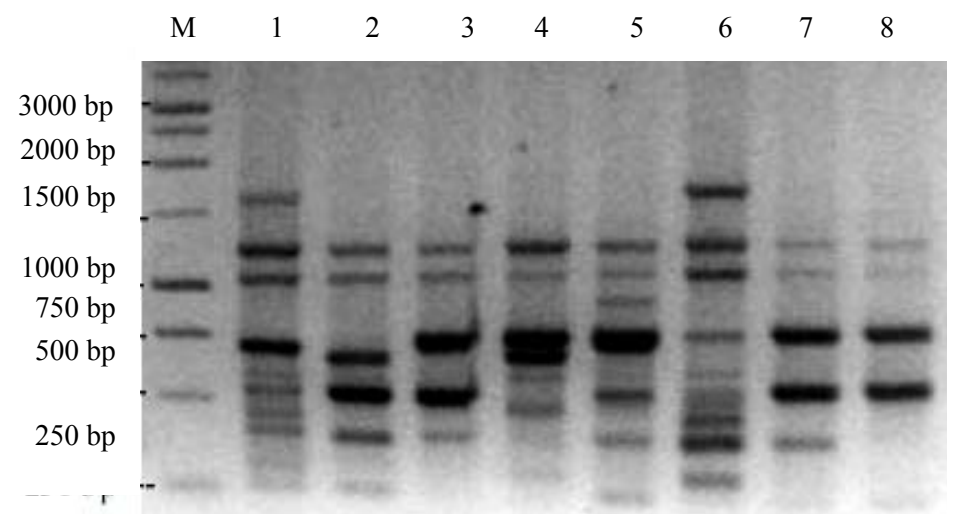

Gambar 1. Pita RAPD dari 8 klon karet dengan primer OPW-19. Lajur (1) RRIC100, (2) RRIM600, (3) GT1, (4) PB260, (5) BPM1, (6) PPN2447, (7) PPN2058, (8) PPN2444; (M) 1-kb DNA Ladder.

Figure 1. RAPD bands of 8 rubber clones with OPW-19 primer. Line (1) RRIC100, (2) RRIM600, (3) GT1, (4) PB260, (5) BPM1, (6) PPN2447, (7) PPN2058, (8) PPN2444; (M) 1-kb DNA Ladder. 
Keragaman genetik klon-klon karet yang resisten dan rentan.....

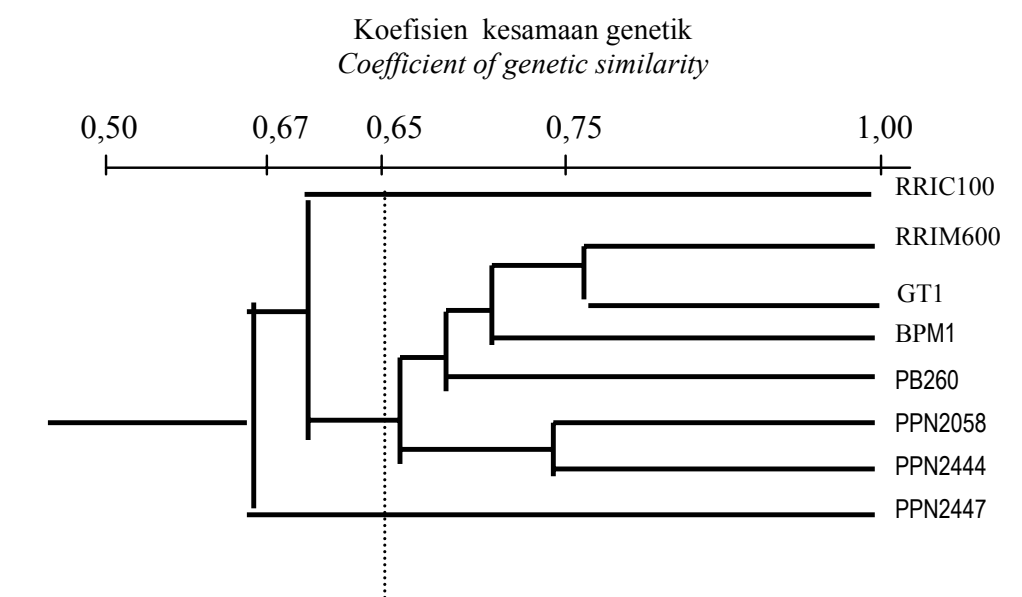

Gambar 2. Dendogram delappan klon karet dari hasil analisis klaster dengan metode UPGMA berdasarkan RAPD.

Figure 2. Dendogram of eight rubber clones from the result of cluster analysis with UPGMA method based on RAPD.

Analisis AFLP

Analisis AFLP menunjukkan bahwa amplifikasi DNA dengan 22 pasang primer menghasilkan 585 pita dengan ukuran 40-500 pb dan 198 pita yang polimorfik. Indeks penanda AFLP (AFLP-MI) adalah 3,57. Pada umumnya primer EcoRI dengan dua nukleotida selektif dalam pasangan primer dapat menghasilkan lebih banyak pita daripada EcoRI dengan tiga nukleotida selektif, meskipun tidak selalu meningkatkan jumlah pita yang polimorfis.

Secara proporsional dua per tiga dari fragmen yang teramplifikasi adalah monomorfik untuk seluruh klon yang diuji.

Dari 20 pasang primer selektif yang diuji menunjukkan bahwa pasangan primer $\mathrm{L}$ (EACA/MCAG) menghasilkan satu pita DNA dengan ukuran $110 \mathrm{pb}$ yang ditemukan pada klon karet RRIC100, RRIM600, PB260, GT1 dan BPM1 yang tergolong resisten, sedangkan pada klon lainnya yang tergolong rentan pita
DNA tersebut tidak ditemukan (Gambar 3).

\section{Kombinasi analisis RAPD dan AFLP}

Data RAPD dan AFLP yang dikombinasikan menunjukkan bahwa tipe dendogram penggabungan tersebut mengikuti dendogam AFLP (Gambar 5). Nilai goodness of fit sangat nyata $(\mathrm{r}=0,74, \mathrm{p}<0,01)$. Menurut Rohlf (1993) $r>0,5$ secara statistik sangat nyata pada $\mathrm{p}=0,01$. Matriks koefisien kesamaan genetik antar 8 klon bervariasi dari 0,56 sampai 1,00. Hal ini menunjukkan bahwa polimorfisme antar klon karet yang diuji adalah rendah. Rendahnya polimorfisme pada klon-klon yang diuji tersebut disebabkan memiliki basis genetik yang sangat sempit. Tingkat polimorfisme DNA yang rendah antar klon-klon Hevea, didominasi oleh pita-pita yang dimiliki secara bersama dalam jumlah banyak, yang menunjukkan bahwa genom dari contoh yang dipelajari 
Keragaman genetik klon-klon karet yang resisten dan rentan.....

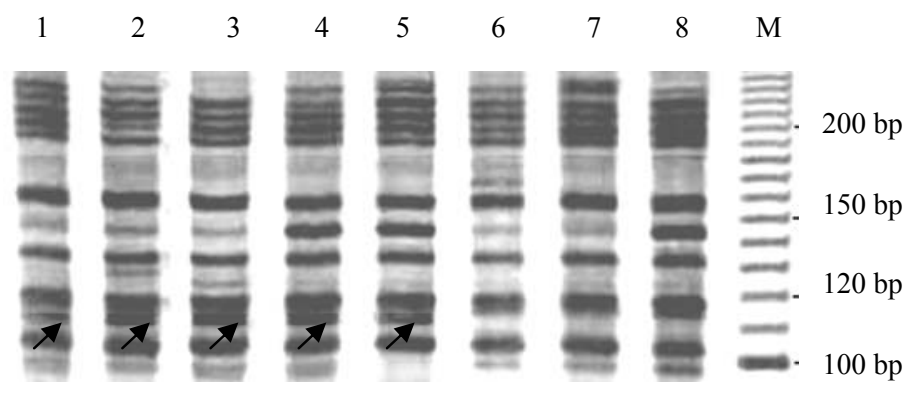

Gambar 3. Pita AFLP dari 8 klon karet. Pita E-ACA/M-CAG 110 merupakan pita DNA yang hanya ditemukan pada klon-klon RRIC100, RRIM600, GT1, PB260, dan BPM1 yang tergolong resisten terhadap penyakit gugur daun Corynespora; Lajur (1) RRIC100, (2) RRIM600, (3) GT1, (4) PB260, (5) BPM1, (6) PPN2447, (7) PPN2058, (8) PPN2444; (M) 30-330 AFLP DNA Ladder.

Figure 3. AFLP bands of 8 rubber clones. E-ACA/M-CAG 110 a specific DNA band which was found only from RRIC100, RRIM600, GT1, PB260, and BPM1. These clones belong to the group resistance to Corynespora; Line (1) RRIC100, (2)RRIM600, (3) GT1, (4) PB260, (5) BPM1, (6) PPN2447, (7) PPN2058, (8) PPN2444; (M) 30-330 AFLP DNA Ladder.

Koefisien kesamaan genetik

Coefficient of genetic similarity

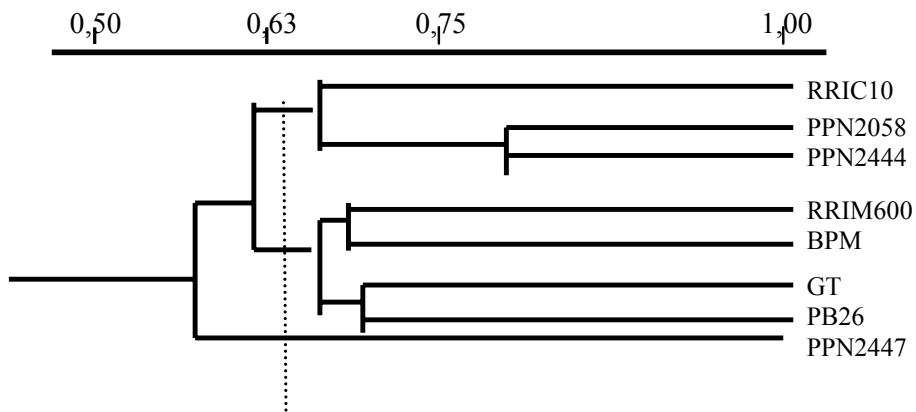

Gambar 4. Dendogram delapan klon karet dari hasil analisis klaster dengan metode UPGMA berdasarkan AFLP.

Figure 4. Dendogram of eight rubber clones from the result of cluster analysis with UPGMA method based on AFLP.

cenderung homogenus. Adanya keragaman genetik antar klon pada tanaman karet sangat penting dalam program pemuliaan untuk perakitan genotip baru, khususnya yang tahan terhadap Corynespora.
Berdasarkan analisis UPGMA kombinasi RAPD dan AFLP menunjukkan bahwa fenogram terbagi menjadi dua kelompok dengan koefisien kesamaan genetik 65\%. Kelompok satu terdiri atas dua sub kelompok 


\section{Toruan-Mathius et al.}

yaitu RRIC 100, dan RRIM 600, GT1, PB260 serta BPM1 yang tergolong resisten, dan sub sub kelompok kedua yang beranggotakan PPN2058, PPN244 yang tergolong rentan. Sedang kelompok dua hanya beranggotakan PPN 2447 (Gambar 5).

Menurut Tohme et al. (1996), Maughan et al. (1996) dan Hill et al. (1996) penggunaan AFLP pada banyak tanaman tidak membutuhkan pengetahuan mengenai sekuen yang ditargetkan, namun mampu mendeteksi setidaknya 10 kali lebih banyak lokus genetik daripada analisis RFLP atau RAPD. Oleh sebab itu penggunaan AFLP memiliki kemampuan untuk mendeteksi ribuan lokus genetik yang independen dalam waktu yang singkat. AFLP memiliki beberapa keunggulan dibandingkan dengan RAPD, diantaranya adalah (i) jumlah lokus DNA yang dapat manfaatkan dalam setiap reaksi lebih banyak, (ii) jumlah fragmen DNA yang diperoleh dari primer yang digunakan lebih banyak, dan (iii) teknik AFLP dalam memunculkan beberapa penanda polimorfik lebih baik. Dari hasil studi ini, setiap kelompok klon karet mampu dipisahkan dengan baik.

Pengelompokan menggunakan RAPD atau AFLP menunjukkan bahwa kedua teknik marka molekuler ini memberikan hasil yang hampir sama, namun tidak identik dalam informasi filogenetiknya. Pengamatan ini ada hubungannya dengan jumlah pita AFLP yang diperoleh dalam analisis dibandingkan dengan pita RAPD yang dapat digunakan. Penetapan keragaman genetik sangat dipengaruhi oleh asesi yang ditetapkan untuk dianalisis dan jumlah penanda yang digunakan.

\section{Tingkat diskriminasi}

Dalam analisis keragaman genetik, ratarata kesamaan genetik pada delapan klon tanaman karet yang diteliti adalah 0,63 (AFLP), 0,67 (RAPD), dan integrasinya adalah 0,65 (AFLP + RAPD). Hasil ini

Koefisien kesamaan genetik

Coefficient of genetic similarity

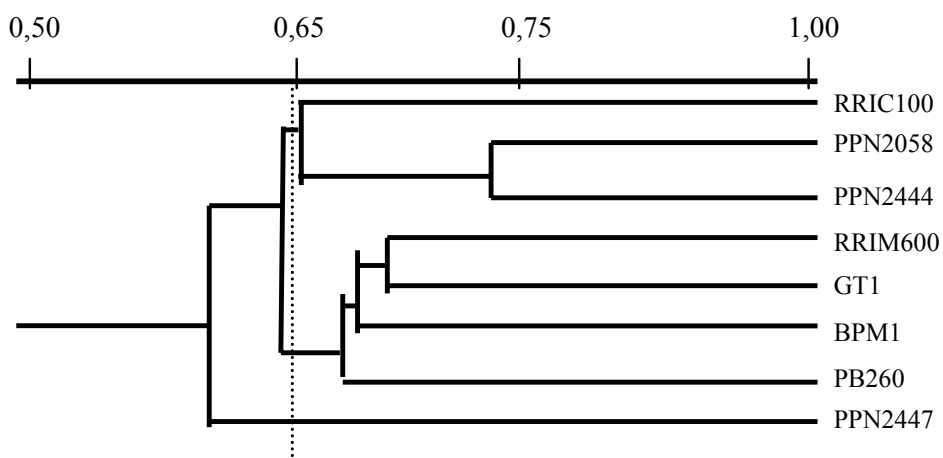

Gambar 5. Dendogram delapan klon karet dari hasil analisis kelompok dengan metode UPGMA berdasarkan RAPD dan AFLP.

Figure 5. Dendogram of eight rubber clones from the result of cluster analysis with UPGMA method based on RAPD and AFLP. 
Keragaman genetik klon-klon karet yang resisten dan rentan.....

menunjukkan bahwa tingkat diferensiasi AFLP dengan 20 PPAS relatif lebih tinggi dari RAPD yang menggunakan 30 primer (Tabel 2).

Interpretasi perbedaan kemampuan suatu sistem marka terhadap marka yang lain dalam mendeteksi keragaman genetik berdasarkan rataan kesamaan genetiknya telah dilakukan oleh Blair et al. (1999) pada tanaman padi. Dilaporkan bahwa rataan kesamaan genetik ISSR dan AFLP berturut-turut adalah 0,55 dan 0,73 dan disimpulkan bahwa kemampuan diskriminasi ISSR lebih tinggi dari pada AFLP.

\section{Pola pengelompokan dendogram}

Analisis korelasi kofenetik menunjuk-kan bahwa analisis pengelompokan ber dasarkan data AFLP mempuyai nilai $r=0,81$ $(\mathrm{p}<0,01)$ dan nilai $\mathrm{r}$ RAPD adalah $0,87(\mathrm{p}<$ $0,01)$ dan nilai $r$ integrasinya adalah $0,90(\mathrm{p}$ $<0,01)$. Hal ini berarti bahwa masingmasing fenogram yang dihasilkan dari metode pengelompokan UPGMA berdasarkan matriks kesamaannya terdapat goodness of fit dalam katagori baik.

Fenogram dari hasil analisis UPGMA berdasarkan RAPD dan AFLP (Gambar 4 \& 5) tampak bahwa pada nilai rata-rata indeks kesamaannya masing-masing marka memberikan pengelompokan yang agak berbeda.
Di samping itu rata-rata perkiraan kesamaan genetik AFLP relatif lebih kecil dari pada RAPD, yang berarti bahwa jarak genetik yang dapat diungkapkan AFLP relatif lebih tinggi dari pada RAPD. Hal ini menunjukkan bahwa AFLP lebih tinggi tingkat diskriminasinya dibandingkan dengan RAPD.

Perbedaan yang paling jelas antara fenogram yang dihasilkan RAPD dan AFLP adalah berkaitan dengan klon RRIC100. Pada analisis RAPD, RRIC100 merupakan klon yang terpisah dari kelompok utama yang terdiri dari 6 klon. Klon RRIM 600 dan GT1 memiliki koefisien kesamaan genetik yang paling tinggi disusul oleh koefisien kesamaan antara PPN2058 dan PPN2444. Sedangkan hasil AFLP menunjukkan bahwa RRIC100 membentuk kelompok dengan PPN2058 dan PPN2444. Kelompok ini mempunyai nilai kofenetik pada kira-kira 0,61 dengan kelompok lain yang terdiri dari RRIM600, BPM1, GT1 dan PB260. PPN2058 dan PPN2444 merupakan dua klon yang kesamaan genetiknya paling tinggi.

Fenogram yang dihasilkan AFLP dan RAPD juga menunjukkan bahwa klon RRIM600, GT1, BPM1 dan PB260 membentuk satu kelompok, walaupun pasangan antara klon terlihat berbeda. Secara keseluruhan analisis kelompok berdasarkan data AFLP dan RAPD tidak jauh berbeda karena korelasi kofenetik antara keduanya yang

Tabel 2. Analisis indeks marka berdasarkan sidikjari sistem marka AFLP dan RAPD.

Table 2. Analysis of marker index based on finggerprinting AFLP and RAPD systems.

\begin{tabular}{lccccccc}
\hline $\begin{array}{l}\text { Sistem Marka } \\
\text { Marker system }\end{array}$ & $\mathrm{JUA}^{1}$ & $\mathrm{JP}^{2}$ & $\mathrm{MR}^{3}$ & $\beta^{4}$ & $\mathrm{E}^{5}$ & $\mathrm{PIC}^{6}$ & $\mathrm{MI}^{7}$ \\
\hline AFLP & 20 & 585 & 29,25 & 0,34 & 9,92 & 0,36 & 3,57 \\
RAPD & 30 & 169 & 5,63 & 0,56 & 3,20 & 0,32 & 1,02 \\
\hline
\end{tabular}


Toruan-Mathius et al.

nyata $(\mathrm{r}=0,74 ; \mathrm{p}<0,01)$. Rohlf (1993) menyatakan bahwa $r>0,5$ digolongkan nyata secara statistik pada $\mathrm{p}=0,01$.

Berdasarkan fenogram yang dibentuk melalui penggabungan data AFLP dengan RAPD terlihat bahwa pola pengelompokan yang terbentuk cenderung mengikuti pola pengelompokan AFLP secara sendiri (Gambar 5). Hasil analisis pengelompokan berdasarkan kombinasi ini merupakan hasil yang paling baik karena merupakan gabungan dari dua kelompok lokus yang dihasilkan dari RAPD dan AFLP. Pada umumnya ketepatan perkiraan akan meningkat apabila jumlah lokus yang terdeteksi dalam analisis meningkat (Lu et al., 1996). Lebih jauh lagi dengan mengasumsikan bahwa semakin tinggi jumlah marka akan menurunkan kesalahan acak pengambilan contoh yang dapat menyebabkan bias pada perkiraan kesamaan genetik (Prabhu et al., 1997), maka perkiraan dengan AFLP akan lebih baik karena menggunakan 198 lokus dibanding-kan dengan RAPD yang jumlahnya sekitar $50 \%$ yaitu 96 lokus. Melchinger (1999) menjelaskan bahwa tingkat ketepatan dalam perkiraan jarak genetik tergantung dari jumlah assay dari suatu marka, genom yang dapat dicakup dan tingkat polimorfisme dari tanaman yang diuji. Dengan demikian maka AFLP lebih disarankan, dan akan lebih baik lagi jika dikombinasikan dengan RAPD dan mikrosatelit dalam analisis keragaman genetik plasma nutfah karet yang akan bermanfaat sebagai referensi yang baik untuk tujuan tertentu program pemuliaan tanaman karet.

Hasil pengelompokan juga menunjuk-kan bahwa klon yang mempunyai salah satu tetua yang sama tidak berada pada kelompok yang sama, misalnya RRIC100 dan RRIM600. Nurhaimi-Haris et al. (1998) dengan menggunakan 10 primer RAPD menunjukkan hal yang sama, misalnya RRIC100 dan RRIM600 yang salah satu tetuanya adalah
PB86, pada fenogram kedua klon tersebut terdapat pada kelompok besar yang berbeda yaitu masing-masing pada kelompok yang terdiri dari 47 klon (RRIC100) dan kelompok lainnya yang terdiri dari 17 klon (RRIM600). Kedua klon ini memiliki nilai koefisien kesamaan genetik pada sekitar 0,72. Di samping itu PPN2447 yang merupakan keturunan illegitim dari LCB1320 memiliki nilai kofenetik pada 0,72 dengan tetuanya tersebut. Dalam penelitian ini PPN2447 dan PPN2444 yang sama-sama merupakan keturunan illegitim dari LCB1320 tidak berada dalam kelompok yang sama. Klon PPN2447 bebas dan memiliki nilai kesamaan yang paling rendah terhadap 7 klon lainnya (RRIC100 dengan 6 klon pada kelompok utama), sementara itu PPN2444 membentuk kelompok dengan PPN2058 cenderung memiliki jarak genetik yang lebih tinggi terhadap klon lainnya (termasuk RRIM600, GT1 dan PB260). Selanjutnya dijelaskan bahwa terdapat klon karet yang sangat dekat berdasarkan fenogram namun tidak memiliki hubungan menurut informasi silsilah.

Menurut Varghese et al. (1997) hal ini dapat terjadi karena tanaman karet yang secara umum merupakan tanaman yang menyerbuk silang dimana hibrid F1 difiksasi secara vegetatif, dan klon-klon tersebut sangat heterozigous. Sebagai akibat dari segregasi dan independent assortment, menyebabkan proporsi dari alel-alel pada hibrid dari setiap tetuanya dapat sangat bervariasi. Hal ini dapat menyebabkan tetua dan hibrid mungkin tidak berada dalam satu kelompok secara bersama. Oleh karena itu tanaman karet yang merupakan spesies heterozigos yang saat ini dibudidayakan hanya terbatas dari Wickham gene pool tersebut, maka informasi tetua mungkin tidak selalu menunjukkan hubungan genetik yang pasti.

Basis genetik tanaman karet sempit, paling tidak karena terbatas pada beberapa 
Keragaman genetik klon-klon karet yang resisten dan rentan.....

tanaman yang dapat bertahan dari koleksi awal Wickham gene pool yang berasal dari Amazon, Brazil yang diintroduksi oleh Sir Henry Wickman pada tahun 1876. Proses seleksi yang dilakukan secara terus menerus terhadap populasi dasar tersebut semakin mempersempit keragaman genetiknya (Varghese et al., 1997; Benong et al., 1996). Walaupun demikian dalam percobaan ini terlihat bahwa baik RAPD maupun AFLP dapat membedakan setiap klon terhadap yang lainnya, dan rata-rata ESG yang ditunjukkan oleh masing-masing marka berkisar 0,65 (koefisien Dice). Hal ini menunjukkan bahwa pada beberapa klon elit tanaman karet masih terdapat keragaman genetik, walaupun relatif sempit. Untuk memperlebar basis genetik perlu dilakukan introduksi material genetik baru.

AFLP sebagai suatu marka molekuler telah banyak dimanfaatkan baik dalam studi keragaman genetik misalnya pada tanaman kakao (Perry et al., 1998) dan kapas (Pillay \& Myers, 1999). Teknik ini juga telah banyak digunakan dalam studi keterpautan dengan sifat tertentu misalnya sifat ketahanan terhadap Cladosporium fulvum pada tomat (Thomas et al., 1995), sifat ketahanan terhadap Melampsora larici-populina pada Populus (Cervera et al., 1996); identifikasi marka AFLP yang terpaut dengan gen avirulen alm1 pada Leptosphaeria maculans (Pongam et al., 1998). Berdasarkan hasil penelitian yang diperoleh analisis AFLP dapat digunakan untuk memetakan gen yang terpaut dengan ketahanan tanama karet terhadap PGDC, apabila populasi yang mewakili untuk dianalisis tersedia di lapang.

\section{Kesimpulan}

Analisis keragaman genetik beberapa klon karet menggunakan marka RAPD dan AFLP menunjukkan bahwa :
1. Marka indeks AFLP lebih tinggi daripada RAPD, sehingga AFLP lebih efektif dibandingkan dengan RAPD.

2. Rata-rata perkiraan kesamaan genetik AFLP sedikit lebih rendah dari RAPD sehingga AFLP relatif lebih diskriminatif daripada RAPD.

3. Dendogram berdasarkan integrasi AFLP dan RAPD paling baik, dimana pada ratarata perkiraan kesamaan genetik 0,65 , terbentuk dua klaster yaitu kelompok A (RRIC100, PPN2058 dan PPN244 yang tergolong rentan) dan kelompok B (RRIM600, GT1, BPM1 dan PB 260 yang tergolong resisten). Sedangkan PPN2447 yang tergolong rentan tidak termasuk dalam kedua kelompok tersebut.

4. Analisis AFLP menghasilkan pita DNA EACA/MCAG ${ }_{110}$ yang berpotensi sebagai kandidat penanda untuk membedakan kelompok tanaman karet yang resisten dan rentan terhadap PGDC.

\section{Daftar Pustaka}

Blair, M. W., O. Panaud, S. R. McCouch (1999). Intersimple sequence repeat (ISSR) amplification for analysis of microsatellite motif frequency and fingerprinting in rice (Oryza sativa L.). Theor. Appl. Genet., 98, 780-792.

Benong, M., O. Hashim \& R. Othman (1996). Evaluation, utilisation and conservation of Hevea germplasm. In S. C. Quah et al. (eds.). Underutilised tropical plant genetics resourcesconservation and utilization. Kuala lumpur, Universiti Pertanian Malaysia Press.

Besse, P., M. Seguin, P. Lebrun, M. H. Chevallier, D. Nicolas \& 
C. Lanaud (1994). Genetic diversity among wild and cultivated populations of Hevea brasiliensis assessed by nuclear RFLP analysis. Plant. Mol. Biol. Rep., 18, 235-241.

Cervera, M.T., J. Gusmao, M. Steenackers, J. Peleman, V. Storme, A. Vanden Broeck, M. Van Montagu \& W. Boerjan (1996). Identification of AFLP molecular markers for resistance against Melampsora larici-populina in Populus. Theor. Appl. Genet., 93, 733-737.

Chaidamsari, T. \& A. Darussamin (1993). Polimorfisme beberapa tetua dan hasil persilangan Hevea brasiliensis Muell Arg. Menara Perkebunan, 61(2), 32-38.

Chevallier, M. H. (1988). Genetic variability of Hevea brasiliensis germplasm using isozymes markers. J. Nat. Rubb. Res., 3 (1), 42-53.

Hill, M., H. Wiotsenboer, M. Zubeau, P.Vos, R. Kesseli \& R. Michelmore (1996). PCR-based fingerprinting using AFLPs as a tool for studying genetic relationships in Lactuca spp. Theor. Appl. Genet., 93, 1202-1210.

Jayasinghe, C. K. \& W. P. K. Silva (1996). Current status of Corynespora leaf fall in Sri Lanka. In Proc. Workshop on Corynespora leaf fall disease of Hevea rubber. Medan, 16-17 December, 1996. p.15-19.

Karp, A., O. Seberg \& M. Buiatti (1996). Molecular techniques in the assesment of botanical diversity. Ann. Bot., 78, 143149.

Lapitan, N. L. V. (1992). Organization and evolution of higher plant nuclear genomes. Genome, 35, 171-181.
Lu, J., M. R. Knox, M. J. Ambrose, J. K. Brown \& T. H. N. Ellis (1996). Comparative analysis of genetic diversity in pea assessed by RFLP- and PCR based methods. Theor. Appl. Genet., 93, 11031111

Mantel, N (1967). The detection of disease clustering and a generalized regression approach. Cancer Res., 27, 209-220.

Maughan, P. J., M. A. S. Maroof, G. R. Buss \& G. M. Huestis (1996). Amplified fragment length polymorphism (AFLP) in soybean: Species diversity, inheritance and near-isogenic line analysis.Theor. Appl. Genet., 76, 815829.

Melchinger, A. E. (1999). Genetic diversity and heterosis. In J.G. Coors \& S. Pandey. The genetics and exploitation of heterosis crops. Madison, American Society of Agronomy, Inc.

Nurhaimi-Haris, S. Woelan \& A. Darussamin (1998). RAPD analysis of genetic variability in plant rubber (Hevea brasiliensis Muell Arg.) clones. Menara Perkebunan, 66 (1) 9-19.

Orozco-Castillo, K., J. Chalmers, R. Waugh \& W. Powell (1994). Detection of genetic diversity and selective gene introgression in coffee using RAPD markers. Theor. Appl. Gent., 87, 934-940.

Paul, S., F. N. Wachira, W. Powell \& R. Waugh (1997). Diversity and genetic differentiation among populations of Indian and Kenyan tea (Camelia sinensis (L) O Kuntze) revealed by AFLP markers. Theor. Appl. Genet., 94, 255263. 
Keragaman genetik klon-klon karet yang resisten dan rentan.....

Perry, M. D., M. R. Davey, J. B. Power, K. C. Lowe \& H. F. J. Blig (1998). DNA isolation and AFLP genetic fingerprinting Theobroma cacao (L.). Plant Mol. Biol. Rep., 16, 49-59.

Pillay, M. \& G. O. Myers (1999). Genetic diversity in cotton assessed by variation in ribosomal DNA genes and AFLP markers. Crop Sci., 39, 1881-1886.

Pongam, P., T. C. Osborn \& P. H. Williams (1998). Genetic analysis and identification of AFLP markers linked to the almI gene of Leptosphaeria maculans. Phytophatol., 88, 1068-1072.

Powell, W., M. Morgante, C. Andre, M. Hanafey, J. Vogel, S. Tingey \& A. Rafalski (1996). The comparison of RFLP, RAPD, AFLP and SSR (microsatellite) markers for germplasm analysis. Mol. Breed., 2, 225-238.

Prabhu, R. R., D. Webb, H. Jenssen, S. Luk, S. Smith \& P. M. Gresshoff (1997). Genetic relatedness among soybean genotypes using DNA amplification fingerprinting (DAF), RFLP, and pedigree. Crop Sci., 37, 1590-1595.

Rajalaksmy, V.K. \& R. Kothandaraman (1996). Current status of Corynespora leaf fall in India. In Proc. Workshop on Corynespora leaf fall disease of Hevea rubber. Medan, 16-17 December, 1996. p.37-43.

Rohlf, F. J. (1993). NTSYS-PC. Numerical Taxonomy and Multivariate Analysis System. Version 1.8. New York, Exeter Software. p. 10-13.

Sambrook, J., E. F. Fritsch \& T. Maniatis (1989). Molecular Cloning: $a$ Laboratory Manual, $2^{\text {nd }}$ ed. New York, Cold Spring Harbor Laboratory Press.
Seguin, M., P. Besse, P. Lebrun \& M.H. Chevallier (1995). Hevea germplasm characterization using isozymes and RFLP markers. In W.T. Baradat - Adams \& Muller-Starck (eds.) Population genetics and genetics conservation of forest trees. p. 129-133.

Shukor, S. K. A., \& S. M. Hidir (1996). Current status of Corynespora leaf fall in Malaysia. In Proc. Workshop on Corynespora leaf fall disease of Hevea rubber. Medan, 16-17 December, 1996. p. 21-28.

Sinulingga, W., Suwarto \& H. Supena (1996). Current status of Corynespora leaf fall in Indonesia. In Proc. Workshop on Corynespora leaf fall disease of Hevea rubber. Medan, 16-17 December, 1996. p. 29-36.

Thomas, C. M., P. Vos, M. Zabeau, D. A. Jones, K. A. Norcott, P. Chadwick \& J. D. G. Jones (1995). Identification of amplified restriction fragment polymorphism (AFLP) markers tightly linked to the tomato $c f-9$ gene for resistance to Cladosporium fulvum. The Plant J., 8, 785-794.

Tohme, J., D. O. Gonzales, S. Beebe \& C. Duque (1996). AFLP analysis of gene pools of a wild bean core collection. Crop Sci., 36, 1375-1384.

Varghese, Y. A., C. Knaak, M. R. Sethuraj \& W. Ecke (1997). Evaluation of random amplified polymorphic DNA (RAPD) markers in Hevea brasiliensis. Plant Breeding, 116, 47-52.

Venkatachalam, P., S. Thomas, P. Priya, I. Thanseem, T. Gireesh, C.K. Saraswathyamma \& A. Thulaseedharan (2002). Identification of DNA poly- 
Toruan-Mathius et al.

morphism among clones of Hevea brasiliensis Muell Arg. Using RAPD analysis. Indian J. Nat. Rubb. Res., 15 (2), 172-181.

Yap. I. V. \& R. J. Nelson (1996). WinBoot. Manila, IRRI Manila. p.22-25.

Yeang, H.Y., E. Sunderasa, R. Wickneswar, D. Napi \& A. S. M. Zamri (1998).
Genetics relatedness and identities of cultivated Hevea clones determined by isozymes. J. Rubb. Res., 1(1), 35-47.

Yee, E., K. K. Kidwell, G. H. R. Sills \& T. A. Lumpkin (1999). Diversity among selected Vigna angularis (Azuki) accessions on the basis of RAPD and AFLP markers. Crop Sci., 39, 268-275. 